\title{
Effectiveness of a stay posting at Primary Health Centres for medical graduates
}

\author{
Dinesh Kumar ${ }^{1}$, Udayshankar Singh ${ }^{2}$, Raithatha Shyamsundar ${ }^{3}$
}

\section{Introduction}

India is a signatory to 'Health for All' and also one of the foremost endorsers of primary health care model. Primary Health Centres (PHCs) are the final point through which the integrated health services are channelled in India. Given vast number of national programmes, it calls for the medical officer in charge to have considerable administrative skills. Health care delivery system including the field visits is a part of the undergraduate teaching curriculum as per Medical Council of India (MCl) guidelines (MCl 1997). As a part of the $\mathrm{MCl}$ institutional goals the medical undergraduate students should acquire basic management skills in the area of human resources, materials and resource management related to health care delivery (MCl 1997). However studies have shown the PHC related knowledge of the undergraduates to be poor (Bhatnagar S et al. 1994; Rangan S \& Uplekar $M$, 1993). Even though the undergraduates are posted at PHCs during internship, the exposure they get is usually in adequate (Kar $\mathrm{K}$ et al, 2008; Lal S 1998). Furthermore, the duration of internship in community medicine has decreased to 2 months. This calls for incorporating the $\mathrm{PHC}$ management related aspects in undergraduate training itself. We have introduced a stay programme at PHCs for the $3^{\text {rd }}$ phase part 1 students about 2 months before their final examination. This time could be

\footnotetext{
${ }^{1}$.Assistant Professor

2. Professor

3.Postgraduate Resident

Dept of Community Medicine

Pramukhswami Medical College

Karamsad ,Gujarat-388325 India

Corresponding Author

Dr. Dinesh Kumar

Assistant Professor

Dept of Community Medicine

Pramukhswami Medical College

Karamsad ,Gujarat-388325 India

E-mail address: drdineshkl@charutarhealth.org
}

considered optimum as the classroom based teaching would have been finished. We have tried to evaluate the effect of this posting on the PHC related knowledge of the undergraduates.

\section{Subjects and Methods}

The study was conducted with undergraduate $\left(3^{\text {rd }}\right.$ phase, part I) medical students at a medical college in Gujarat, India, in December 2009. Students were residential postings in four PHC villages in groups of 26 under the guidance of the residents and the faculty for 4 days. The main emphasis was on understanding the administrative aspects of PHC. We preferred staying at villages as it takes care of logistics of daily travelling for several days. Also, it provides students extra time beyond the busy office hours to interact with the PHC staff. Certain activities especially those related to immunization that start early in morning can also be observed. It also provides students opportunities to interact with local villagers in a non-formal setting. The functioning of $\mathrm{PHC}$ in two domains; of administration including manpower, material, record keeping, general administration, finances and of services provided in areas of immunization, family planning, National Vector Borne Disease Control Programme, Revised National Tuberculosis Control Programme and School Health programme was studied. The key teaching methods included group discussions, interview of the PHC staff, observation of the activities, analysis of various PHC records and reports. The students were divided into sub groups and assigned tasks to collect data on planning, administration, supervision, monitoring and evaluation aspect of the above mentioned health programmes. Data on planning and administration was collected by interviews, supervision by direct observation and monitoring and evaluation from records. They discussed with medical officers and clerks about the general administration of PHC including financial details. The students also planned and carried out health education 
activities. It was not exactly related to learning about PHC, but was included as token of goodwill for the help provided by local community during the stay. Also it provides students a chance to have hands on experience about this important and often neglected component of Primary Health Care. The evaluation of the posting was carried using multiple choice questions based on these two domains (8 for administration and 9 for services), one day prior and one day after the posting. Each question carried 1 mark and there was no negative mark for the wrong response. Differences between pre and post test scores were analyzed by Wilcoxon signed rank test for paired observation as normal distribution of the scores could not be assumed. All the analysis was carried out using Statistical Programme for Social Sciences (SPSS 15.0).

\section{Results}

Of 103 students 96 (93.2\%) appeared for both the pre-test and post-test assessment and their scores were used for the final analysis. The pre-test score was 10.75 of which $3.47(32.2 \%)$ and $7.23(67.8 \%)$ was from administration domain and service domain respectively. The post-test score was 12.9 of which $5.2(40.3 \%)$ and 7.7 (59.1\%) was from administration domain and service domain respectively. The differences between the pretest and post-test scores were found to be significant for the total score as well as both the domains as shown in table 1 . The positive ranks were 76,42 and 77 for the total, service and administration domains respectively.

Table1. Results of the Wilcoxon Signed Ranks test for the paired pre-test and post-test scores (n=96)

\begin{tabular}{|c|c|c|c|c|c|c|}
\hline & Ranks & $\mathbf{N}$ & Mean Rank & Sum of Ranks & Z score* & $\mathbf{p}$ \\
\hline \multirow{3}{*}{$\begin{array}{l}\text { Post-test - Pretest } \\
\text { scores total }\end{array}$} & Negative & 11 & 22.00 & 242.00 & -7.123 & 0.000 \\
\hline & Positive & 76 & 47.18 & 3586.00 & & \\
\hline & Ties & 9 & & & & \\
\hline \multirow{3}{*}{$\begin{array}{l}\text { Post-test - Pre-test } \\
\text { Service domain }\end{array}$} & Negative & 19 & 22.55 & 428.50 & -3.846 & 0.000 \\
\hline & Positive & 42 & 34.82 & 1462.50 & & \\
\hline & Ties & 35 & & & & \\
\hline \multirow{3}{*}{$\begin{array}{l}\text { Post-test - Pre-test } \\
\text { administration domain }\end{array}$} & Negative & 7 & 32.29 & 226.00 & -7.019 & 0.000 \\
\hline & Positive & 77 & 43.43 & 3344.00 & & \\
\hline & Ties & 12 & & & & \\
\hline
\end{tabular}

${ }^{*}$ calculated for negative ranks.

\section{Discussion}

The pre-test administration score was 3.47 (43.4\% of maximum possible 8 marks) for administration compared to 7.23 (80.3\% of maximum possible 9 marks) for service domain. This is in line with other studies (Bhatnagar et al. 1994; Rangan \& Uplekar, 1993) and points to the poor knowledge of undergraduates related to administrative aspects of PHCs which is usually not a part of traditional classroom teaching.

There was a gain in the overall score in both the domains and the differences were statistically significant. The maximum gain was in the administration domain. This was in line with the planned objective of the posting. Also the positive ranks in administration domain were even greater than the total score, signifying that students who did not improve in their total score improved in the administration domain.

Even though there was a significant immediate improvement in knowledge, the same may not persist after duration of a few years when such knowledge will have to be actually used. However this could be supplemented by refresher courses during internship for a long term effect.

We recommend such PHC stay postings with special emphasis on administrative aspects to be adopted by other medical colleges. 


\section{Acknowledgements}

We would like to acknowledge the active initiative taken by all the faculty of the department of Community Medicine at PSMC Karamsad Gujarat, especially Dr.Vasudev Rawal in designing and implementing the PHC stay programme. We would also like to acknowledge the logistic support provided by the Pramukhswami Medical College.

\section{References}

Bhatnagar, S., Nath, D.H., Banerjee, A., Trakroo, P.L., Murali, I. \& Singhal, D.S. (1994) A status study of training in $\mathrm{MCH} \& \mathrm{FW}$ medical college of India, Health and Population - Perspectives \& Issues, 17, 3\&4, pp. 190-218.
Kar, K., Panda, M. \& Mahapatra, B. (2008) Knowledge of the interns on health care delivery system. Available at: http://www.jcmorrisaa.org/ index_ files/page4572.htm. [Accessed 26 Feb 2010].

Lal, S. (1998) Status of health management training in medical colleges, Indian J Community Med, 23, (3), pp. 95-8.

Medical Council of India. (1997) 1. Graduate Medical Education regulations, Available at: http://mciindia.org/ know/rules_mbbs.htm. [Accessed 3 Feb 2010].

Rangan, S. \& Uplekar, M. (1993) Community health awareness among recent medical graduates of Bombay, Natl Med J India, Mar-Apr, 6, 2, pp. 60-4. 